\title{
CORPORATE VOCATIONAL SCHOOL: STRATEGI ANTISIPATIF MENGHADAPI PENGANGGURAN LULUSAN SMK DALAM PERSPEKTIF BONUS DEMOGRAFI
}

\author{
Tarma \\ Universitas Negeri Jakarta \\ Email:tarmasae@gmail.com
}

\begin{abstract}
Abstrak
Pengangguran merupakan salah satu ancaman menjelang fenomena bonus demografi. Institusi pendidikan vokasi bertanggung jawab mengantisipasi hal tersebut. Sekolah Menengah Kejuruan (SMK) yang diharapkan menjadi solusi, justru menempatkan lulusanya menjadi kontributor terbesar pengangguran sebesar $11,19 \%$ (data BPS tahun 2013). Pengangguran lulusan SMK disebabkan oleh kesenjangan antara tenaga kerja dengan kebutuhan penyedia lapangan pekerjaan. Untuk itu diperlukan "corporate vocational school", yaitu konsep sekolah kejuruan yang dimiliki perusahaan serta terintegrasi dan in line dengan manpower planning yang ada di perusahaan tersebut. Konsep "corporate vocational school" merupakan down grade dari konsep "corporate university" yang sudah lebih dulu eksis. Dalam corporate vocational school, bidang keahlian yang dipelajari sesuai dengan core business perusahaan. Kultur akademik terintegrasi dengan kultur kerja perusahaan. Model pembelajaran dirancang dengan work real life based. Standar lulusan sesuai dengan kriteria minimal atau job requirement dari posisi pekerjaan yang telah diproyeksikan sebelumnya. Sehingga lulusan dari sekolah ini langsung dapat diserap serta langsung tune in dengan pekerjaan.
\end{abstract}

Kata Kunci: Pengangguran, SMK, Corporate Vocational School

\section{PENDAHULUAN}

Berdasarkan proyeksi kependudukan, pada tahun 2020-2030 akan terjadi fenomena dimana penduduk usia produktif (15-64 tahun) di Indonesia mencapai $60 \%$ atau $160-180$ juta jiwa (Suyono dalam Konadi dan Iba, 2011:18). Hal inilah yang disebut sebagai bonus demografi, dimana penduduk usia produktif hanya menanggung 3-4 orang usia tidak produktif. Bila penduduk usia produktif tersebut disiapkan dengan baik melalui pendidikan, pelatihan, kesehatan, penyediaan lapangan kerja dan investasi maka akan berdampak pada kesejahteraan bangsa.

Fenomena tersebut bagaikan dua sisi mata uang. Bila mampu mempersiapkan generasi maka akan memperoleh keuntungan yang melimpah akan terjadi bonus demografi yang mensejahterakan bangsa. Sebaliknya bila gagal dalam mengantisipasi, maka peluang munculnya ancaman bencana demografi yang sangat merugikan. Dimana pengangguran, kemiskinan, dan kriminalitas yang tinggi.
Salah satu fenomena yang akan terjadi bila antisipasi terhadap bonus demografi tidak berjalan dengan baik adalah pengangguran. Dalam konteks tersebut, peran lembaga pendidikan sebagai institusi penyiapan tenaga kerja menjadi sangat berperan, terutama pendidikan teknologi dan kejuruan. Sebagaimana kodratnya pendidikan kejuruan yang berfungsi di antaranya: "membekali peserta didik dengan kemampuan ilmu pengetahuan dan teknologi serta kecakapan kejuruan para profesi sesuai dengan kebutuhan masyarakat" (PP No. 17 Tahun 2010 Tentang Pengelolaan Dan Penyelenggaraan Pendidikan Pasal 76 ayat (2) poin C).

Meskipun Sekolah Menengah Kejuruan (SMK) lulusannya diorientasikan untuk siap bekerja, namun faktanya masih banyak yang belum terserap oleh dunia kerja. Rilis BPS pada bulan November 2013 menyebutkan bahwa lulusan SMK sebagai lulusan terbanyak yang belum terserap oleh dunia kerja yakni $11,9 \%$ dari 7,4 orang. Pengangguran memang 
disebabkan oleh banyak faktor, di antaranya adalah kesenjangan antara kualitas lulusan SMK dengan kualitas yang dibutuhkan oleh dunia kerja. Meskipun berbagai upaya telah dilakukan untuk mengurangi kesenjangan antara kebutuhan dunia kerja dengan kualitas lulusan pendidikan, seperti dengan penerapan link and match, pendidikan sistem ganda, dan magang atau praktek kerja lapangan; namun upaya tersebut masih belum mencapai hasil yang diharapkan. Untuk itu, diperlukan alternatif lain agar lulusan SMK mendekati $100 \%$ yang terserap oleh pasar kerja.

\section{KAJIAN TEORI}

\section{Perencanaan Pendidikan Ketenagakerjaan}

Di antara pendekatan dalam perencanaan pendidikan ialah pendekatan perencanaan tenaga kerja. Yaitu perencanaan pendidikan yang diarahkan agar tercipta lulusan yang memiliki skill yang dibutuhkan dunia kerja dan perkembangan zaman (Engkoswara dan Komariah, 2010:133). Menurut Guruge (Sa'ud dan Makmun, 2011:240), pendekatan ketenagakerjaan merupakan pendekatan pendidikan yang bertujuan mengarahkan kegiatan pendidikan kepada usaha untuk memenuhi kebutuhan nasional akan tenaga kerja (man power atau person power).

Lebih lanjut Sa'ud dan Makmun (2011:240) menyatakan bahwa pendekatan ini mengutamakan kepada keterkaitan lulusan sistem pendidikan dengan tuntutan terhadap tenaga kerja pada berbagai sektor pembangunan. Tujuan yang akan dicapai adalah bahwa pendidikan diperlukan untuk membantu lulusan memperoleh kesempatan kerja yang lebih baik. Pendekatan ini menekankan relevansi program pendidikan dengan berbagai bidang pekerjaan. Pendidikan kejuruan dan teknologi merupakan prioritas dalam pendekatan ini. Dalam pendekatan ini, kurikulum dikembangkan sedemikian rupa sehingga lulusan siap pakai di lapangan. Jenis pekerjaan, tingkat atau level pekerjaan, persyaratan kerja, mobilitas kerja harus dijabarkan dengan tepat dalam pendidikan di sekolah/universitas.

\section{Strategis Human Resources Management}

Manajemen Sumber Daya Manusia (SDM) merupakan keseluruhan proses pendayagunaan sumber daya manusia dari mulai perencanaan, perekrutan, pengembangan sampai pemberhentian untuk mencapai tujuan organisasi. Sumber daya manusia merupakan aset yang paling berharga bagi perusahaan. Oleh karenanya, sumber daya manusia yang ada di perusahaan harus dikelola dengan baik.

Perusahaan merupakan sistem terbuka yang dinamis serta harus adaptif bahkan antisipatif terhadap perubahan. Sumber perubahan dapat berasal dari lingkungan eskternal seperti perubahan ekonomi, perkembangan tekologi, perubahan geografi, perkembangan kependudukan, perubahan pemerintahan dan perubahan sosial. Perubahan dari dalam perusahaan misalnya perubahan visi, misi, strategi, core business, produk, standar mutu, sistem pekerjaan, tuntutan pegawai dan sebagainya. Perubahan tersebut menuntut adanya perubahan dalam manajemen sumber daya manusia, termasuk kompetensi yang dibutuhkan di masa yang akan datang oleh perusahan tersebut. Untuk itu, maka perusahaan harus melakukan perencanaan strategis. Menurut Rothwel Dan Kazanas (2003:Xv): "strategic planning for human resources (SPHR) as the process of anticipating longterm $\mathrm{hr}$ supplies and demands relative to changing conditions inside and outside an organization....". Berdasarkan pendapat tersebut dapat dipahami bahwa perencanaan strategis sumber daya manusia merupakan proses mengantisipasi masukan dan kebutuhan sumber daya manusia jangka panjang untuk mengantisipasi perubahan yang ada di dalam dan di luar perusahaan.

Berkenan dengan strategi perusahaan, menurut Rothwel Dan Kazanas (2003:7), ada tiga tingkatan strategi, yaitu: (1) corporate, yaitu strategi yang mencakup keseluruhan perusahaan; (2) business, yaitu strategi suatu usaha tertentu dalam perusahaan; dan (3) functional, yaitu strategi yang mencakup manajer dari produk yang berbeda, area geografis, atau aktivitas seperti keuangan dan manajemen SDM. Untuk masing-masing tingkatan tersebut berdampak pada sumber daya manusia yang dibutuhkan oleh perusahaan.

Untuk mempersiapkan kebutuhan SDM tersebut, perusahaan dapat mengembangkan SDM yang ada agar sesuai dengan tuntutan kompetensi yang dipersyaratkan atau dengan merekrut pegawai baru yang cocok. Atau dapat pula dengan merekrut pegawai berbakat untuk di didik menjadi pegawai sesuai dengan standar kompetensi yang dibutuhkan. 


\section{Corporate University}

Corporate University pertama kali dilakukan oleg general motor pada tahun 1920 . Menurut Dufour dan Wargnier (2010:6), dewasa ini biaya untuk mengadakan pelatihan di perancis sebesar 6-7\% dari biaya gaji. Secara definisi, Hawthorne, Libby, and Nash (dalam Allen, 2010) Mendefinisikan Corporate University sebagai: pendidikan gelar dan non gelar yang ditetapkan oleh entitas profit maupun nonprofit. Pandangan lain menyatakan bahwa Corporate University merupakan departemen pelatihan yang ada untuk melatih pegawai tentang pekerjaan spesifik tertentu (Edelstein dan Armstrong dalam Allen 2010). Corporate University di definisikan pula sebagai lembaga pendidikan yang merupakan alat strategis yang dirancang untuk membantu organisasi induknya guna mencapai misinya dengan melakukan aktivitas pembelajaran, pengetahuan dan kebijaksanaan individu maupun organisasi.

Dari definisi Corporate University yang terakhir disebutkan, dapat dimaknai bahwa esensi keberadaan Corporate University adalah untuk mempersiapkan atau mengembangkan SDM untuk kepentingan strategis organisasi.

Allen (2010) mengidentifikasi empat level dari Corporate University, Yaitu: (1) Hanya Pelatihan, Yakni Corporate University dipandang sebagai departemen pelatihan yang melatihkan pekerjaan spesifik pada pegawai; (2) pelatihan ditambah pengembangan manajerial atau eksekutif; (3) melakukan kursus yang memiliki bobot kredit akademik sehingga dapat ditransfer ke pendidikan akademik lainnya; dan (4) melakukan kursus atau pembelajaran yang bersifat program gelar.

\section{PEMBAHASAN}

\section{Apakah Corporate Vocational School?}

Bila institusi pendidikan yang berafiliasi dengan perusahaan untuk jenjang pendidikan tinggi atau pendidikan setelah lulus sekolah menengah disebut Corporate University, maka yang dimaksud dengan Corporate Vocational School adalah sekolah menengah kejuruan yang berada di bawah naungan atau berafiliasi dengan suatu perusahaan. Tujuan dari adanya sekolah menengah kejuruan adalah untuk menyiapkan tenaga-tenaga terampil dalam pekerjaan tertentu sesuai dengan kebutuhan masyarakat. Dengan kata lain, SMK bertujuan menyiapkan tenaga kerja terampil yang dibutuhkan oleh dunia usaha dan industri. Maka Corporate Vocational School didefinisikan sebagai sekolah kejuruan pada jenjang menengah yang mengembangkan pengetahuan, sikap dan terutama keterampilan peserta didik yang dibutuhkan pada suatu perusahaan di masa mendatang serta untuk mendukung rencana strategis perusahaan tersebut.

Setelah didefinisikan dengan jelas, apa yang dimaksud dengan Corporate Vocational School (CVS), selanjutnya seperti apakah karakteristik dari sekolah tersebut?

a. Organisasi. Secara organisasi, CVS merupakan satuan pendidikan yang diselenggarakan oleh masyarakat. Konkretnya, karena peraturan perundangundangan tidak memungkin secara langsung mendirikan sekolah di bawah perusahaan, maka perusahaan terlebih dahulu membuat yayasan yang berafiliasi atau berada dalam entitas bisnis perusahaan tersebut.

b. Kurikulum. Kurikulum yang digunakan adalah kurikulum nasional dengan penyesuaian secara konkret dengan kriteria kompetensi atau profil kompetensi yang berlaku di perusahaan yang menjadi afiliasinya. Proses penyusunan kurikulum bekerjasama secara langsung dengan departemen SDM di perusahaan dengan penekanan pada kebutuhan strategis perusahaan.

c. Pembelajaran. Proses pembelajaran dirancang mendekati situasi pekerjaan yang sebenarnya terutama untuk mata pelajaran yang sifatnya produktif. Pembelajaran dapat dilaksanakan dalam ruangan/setting 'prototype' tempat kerja atau bila memungkan langsung di tempat pekerjaan yang sesungguhnya. Dalam pembelajaran juga dikenalkan dan dibiasakan menerapkan budaya perusahaan di mana sekolah tersebut berafiliasi.

d. Evaluasi Pembelajaran. Evaluasi pembelajaran, terutama untuk mata pelajaran produktif terintegrasi dengan sistem rekrutmen pegawai di perusahaan. Selain itu, agar penguasaan kompetensi peserta didik diakui oleh profesi atau perusahaan lain, peserta didik diharuskan menempuh uji kompetensi bekerjasama dengan Lembaga Sertifikasi Profesi Pihak 3(LSP-P3).

e. Peserta Didik. Peserta didik adalah anggota masyarakat yang memiliki minat pada bidang pekerjaan dan berminat pula bekerja di perusahaan di mana CVS tersebut berafiliasi. Proses seleksi penerimaan siswa dilakukan secara ketat dengan mempertimbangkan kompetensi awal, talent, prognosis dan analisis psikologis lain yang diperlukan. Selama menjalani pendidikan, siswa diperkenalkan sejak dini dan dibentuk karakternya sesuai dengan 
corporate culture. Selain itu, peserta didik mendapatkan beasiswa serta ikatan dinas.

f. Tenaga Pendidik. Tenaga pendidik yang mengajar di CVS adalah tenaga pendidik sesuai standar kualifikasi dan kompetensi guru. Namun untuk menguatkan, para guru yang ada terlebih dahulu harus lulus orientasi di perusahaan tersebut. Untuk menguatkan pembelajaran, sekolah harus sering mengundang tenaga kerja di perusahaan sebagai 'guru tamu' di sekolah yang mengajarkan kompetensi tertentu.

g. Fasilitas. Fasilitas pembelajaran sedemikan rupa mendekati fasilitas yang ada di perusahaan. Misalnya untuk fasilitas laboratorium dengan spesifikasi yang sama atau hampir mendekati yang digunakan di perusahaan.

h. Pembiayaan. Perusahaan menempatkan sekolah sebagai instrumen investasi bagi perusahaan, khususnya investasi SDM. Sehingga anggaran yang digunakan dapat mengambil dari pos anggaran perekrutan dan pengembangan SDM. Selain itu, perusahaan dapat menggunakan dana tanggung jawab sosial dan lingkungan perusahaan atau dana CSR sesuai dengan Undang-Undang No.40 Tahun 2007 tentang perseroan terbatas. Di mana dana yang dikeluarkan akan memotong pajak yang semestinya dibayarkan.

i. Pengelolaan. Pengelolaan sekolah mengikuti standar yang ada di perusahaan sepanjang tidak berbenturan dengan standar nasional pendidikan yang ada. Misalnya tentang standar pembukuan keuangan yang mengikuti sistem yang ada di perusahaan.

\section{Mengapa Corporate Vocational School?}

Berbagai Upaya Untuk Mengurangi Kesenjangan Antara Kompetensi Lulusan SMK Dengan Kompetensi Yang Dibutuhkan Oleh Perusahaan. Namun Upaya Yang Ada Sifatnya Mendekatkan Atau Mengadopsi Standar Kompetensi Suatu Pekerjaan Yang Ada Di Perusahaan Kemudian Diserap Dalam Kurikulum. Atau Mempersepsi, Menduga, Menganalisis Atau Menebak Kebutuhan Kompetensi Di Perusahaan Yang Kemudian Di formulasikan Menjadi Kurikulum. Dalam Kedua Cara Tersebut Masih Memungkinkan Terjadinya Bias , Baik Bias Dalam Kurikulum Maupun Bias Dalam Implementasi Pembelajaran. Terlebih Bila SMK Tidak Memiliki Fasilitas Yang Memadai Selayaknya Yang Ada Di Perusahaan. Kesenjangan Juga Turut
Disebabkan Oleh Faktor Lain Seperti Kualitas Pendidik Yang Tidak Memiliki Pengalaman Sebagai Praktisi.

Selain Kesenjangan, Juga Efisiensi Menjadi Salah Satu Pendorong Munculnya Pemikiran CVS Ini. Untuk Setiap Pegawai Yang Diterima Yang Berasal Bukan Dari CVS, Maka Diperlukan Biaya Training. Baik Untuk Training Tentang Soft-Skill Yang Dibutuhkan Di Perusahaan, Misalnya Etika, Budaya Perusahaan, Dan Disiplin; Maupun Untuk Hard-Skill Bagi Yang Memiliki Kompetensi Di Bawah Standar Perusahaan. Dengan Asumsi 10 Juta Angkatan Kerja Baru Lulusan SMK Dan Biaya Untuk Training Rp. 1.000.000/Orang Maka Inefisiensi Untuk Pelatihan Sebesar Rp. 10.000.000.000.000 (10 Trilyun).

Setiap Tahun, Jumlah Angkatan Kerja Berdasarkan Tingkat Pendidikannya Membentuk Piramida, Di Mana Lulusan Perguruan Tinggi Menempati Jumlah Lebih Sedikit Dibandingkan Dengan Lulusan SMK Sekalipun (Data BPS Bulan Oktober 2014). Selain Itu, Tidak Semua Pekerjaan Membutuhkan Kualifikasi Diploma Maupun Sarjana. Maka Dengan Mengimplementasikan Maka Akan Mereduksi Dan Mengantisipasi Jumlah Pengagguran Lulus SMK.

\section{Bagaimana Mengimplementasikan Konsep Corporate Vocational School?}

Berbagai upaya untuk mengurangi kesenjangan antara kompetensi lulusan smk dengan kompetensi yang dibutuhkan oleh perusahaan. Namun upaya yang ada sifatnya mendekatkan atau mengadopsi standar kompetensi suatu pekerjaan yang ada di perusahaan kemudian diserap dalam kurikulum. Atau mempersepsi, menduga, menganalisis atau menebak kebutuhan kompetensi di perusahaan yang kemudian diformulasikan menjadi kurikulum. Dalam kedua cara tersebut masih memungkinkan terjadinya bias, baik bias dalam kurikulum maupun bias dalam implementasi pembelajaran. Terlebih bila SMK tidak memiliki fasilitas yang memadai selayaknya yang ada di perusahaan. Kesenjangan juga turut disebabkan oleh faktor lain seperti kualitas pendidik yang tidak memiliki pengalaman sebagai praktisi.

Selain kesenjangan, juga efisiensi menjadi salah satu pendorong munculnya pemikiran CVS ini. Untuk setiap pegawai yang diterima yang berasal bukan dari CVS, maka diperlukan biaya training. Baik untuk training 
tentang soft-skill yang dibutuhkan di perusahaan, misalnya etika, budaya perusahaan, dan disiplin; maupun untuk hard-skill bagi yang memiliki kompetensi di bawah standar perusahaan. Dengan asumsi 10 juta angkatan kerja baru lulusan SMK dan biaya untuk training rp. 1.000.000/orang maka inefisiensi untuk pelatihan sebesar rp. 10.000.000.000.000 (10 trilyun).

Setiap tahun, jumlah angkatan kerja berdasarkan tingkat pendidikannya membentuk piramida, di mana lulusan perguruan tinggi menempati jumlah lebih sedikit dibandingkan dengan lulusan smk sekalipun (data BPS bulan Oktober 2014). Selain itu, tidak semua pekerjaan membutuhkan kualifikasi diploma maupun sarjana. Maka dengan mengimplementasikan maka akan mereduksi dan mengantisipasi jumlah pengagguran lulus SMK.

\section{Bagaimana Mengimplementasikan Konsep Corporate Vocational School?}

Untuk mengimplementasikan konsep Corporate Vocational School diperlukan kerjasama para pihak terkait secara sungguhsungguh dan konsisten. Untuk itu, pemerintah terlebih dahulu mengeluarkan kebijakan bagi perusahaan besar ke atas untuk mendirikan Corporate Vocational School. Secara teknis, langkah implementasi pendirian Corporate Vocational School mengadaptasi tahapan pendirian Corporate University (Dufour dan Wargnier: 2010) sebagai berikut:

1. Set Up. Pada tahap ini aktivitas yang dilakukan adalah: (1) menentukan jenis kejuruan, misi, positioning, dan pengelolaan; (2) menentukan kualifikasi dan nominasi pimpinan corporate vocational school; (3) mendefinisikan parameter; (4) membentuk steering commite atau komite sekolah; dan (5) validasi tujuan Corporate Vocational School.

2. Build. Pada tahap ini yang dilakukan adalah: (1) menetapkan staf; (2) menentukan lokasi dan organisasi secara lengkap; (3) menyusun program dan langkah-langkah cepat; (4) mengidentifikasi sponsor, tenaga pengajar, instruktur lapangan, tenaga ahli dan mitra; dan (5) merencanakan peresmian/pembukaan.

3. Launching. Pada tahap ini yang dilakukan adalah: (1) melakukan kampanye peresmian dan pembukaan Corporate Vocational School; dan (2) melakukan pilot program pertama dan mengukur hasilnya.

4. Operasional. Pada tahap ini yang dilakukan adalah: (1) rapat steering committee membahas perkembangan sekolah; desain dan menjalankan semua program sekolah (strategis, kepemimpinan dan pengembangan kompetensi; mengembangkan organisasi dan budaya perusahaan, dan (4) monitoring pencapaian strategis,laboratorium inovasi, penemuan kembali model.

\section{KESIMPULAN}

Berdasarkan pembahasan tentang Corporate Vocational School di atas, dapat disimpulkan beberapa hal di bawah ini:

1. Corporate Vocational School adalah sekolah kejuruan pada jenjang menengah yang mengembangkan pengetahuan, sikap dan terutama keterampilan peserta didik yang dibutuhkan pada suatu perusahaan di masa mendatang serta untuk mendukung rencana strategis perusahaan tersebut.

2. Corporate Vocational School perlu dilakukandalam rangka: (1) memperkecil kesenjangan antara kompetensi lulusan sekolah dengan kompetensi yang dibutuhkan perusahaan; (2) efisiensi biaya pendidikan dengan mereduksi biaya induction/training/orientasi pegawai; (3) mengantisipasi pengangguran lulusan SMK.

3. Untuk mengimplementasikan Corporate Vocational School diperlukan kerjasama para pihak terkait serta kebijakan pemerintah yang mewajibkan perusahaan besar untuk mendirikan Corporate Vocational School. Langkah implementasi untuk mendirikan Corporate Vocational School yaitu set up, build, launching, operation.

\section{DAFTAR PUSTAKA}

Allen, M. (2010). The Corporate University Handbook. [Online]. Tersedia Di Http://Www.Globalccu.Com/Images201 0/Globalccu-Ebooks/The-CorporateUniversity-Handbook.Pdf.

Badan Pusat Statistik. (2014). Laporan Bulanan Data Sosial Ekonomi. Jakarta: BPS.

Dufour, B Dan Wargnier, J. (2010). Corporate University. Auchan: Crossknowledge Company.

Engkoswara Dan Komariah, A. (2010). Administrasi Pendidikan. Bandung: Alfabeta.

Konadi, W Dan Iba, Z. (2011). Bonus Demografi Modal Membangun Bangsa Yang Sehat Dan Bermartabat. Majalah Variasi Vol. 2 No.6 Hal 18-23. 
6 Jurnal Dinamika Manajemen Pendidikan Vol. 1 No. 1 Tahun 2016 Hal. 1-6

Rothwel, W.J Dan Kazanas, H.C. (2003). Planning And Managing Human Resources. Massachusetts: Human Sa'ud, U.S Dan Makmun, A.S. (2011). Resource Development Press, Inc.

: Remaja Rosdakarya. 